\title{
The Influence of the Selected Determinants on the Development of Small and Medium Enterprises
}

\author{
Anna Lemańska-Majdzik, Małgorzata Okręglicka and Iwona Gorzeń-Mitka
}

Czestochowa University of Technology, Poland

Correspondence should be addressed to: Anna Lemańska-Majdzik; lemanska@zim.pcz.pl

Received date: 24 August 2016; Accepted date: 23 November 2016; Published date: 9 January 2017

Academic Editor: Agnieszka Janik

Copyright (c) 2017. Anna Lemańska-Majdzik, Małgorzata Okręglicka and Iwona Gorzeń-Mitka. Distributed under Creative Commons CC-BY 4.0

\begin{abstract}
The key role of enterprises in the intensification of economic growth of each country causes that the subject of the development of the corporate sector becomes one of the most important issues in the economic literature. The special importance is therefore assigned to identifying and analysing the influence of development determinants and conditions and their intensity on economic businesses. However, the business environment is even more and more complex and changeable, the constant analysis of the enterprise development issue, especially according to SMEs, is highly required. The main aim of the paper is, after the detailed literature review describing conditions and determinants of the development of enterprises, to evaluate selected determinants connected with carrying out business activity that influence the development of micro-, small and medium enterprises from Poland. To realize the aim, there was the questionnaire survey conducted on a group of 250 SMEs in 2016. The authors have used basic statistics and Gamma correlation coefficient to present relationships between research variables.
\end{abstract}

Keywords: development, determinants of development, SME sector

\section{Introduction}

The sector of small and medium enterprises represents the most numerous group of enterprises and accounts for over $99 \%$ of all companies in the European Union economies (Annual Report, 2015). This sector, due to its size and profile, impacts the economic development of individual countries (Ivanová, 2011). High degree of flexibility and ability to adapt to new markets allows micro-, small and medium enterprises to develop as a result of their ability to effectively use resources in the economy.

Cite this Article as: Anna Lemańska-Majdzik, Małgorzata Okręglicka and Iwona Gorzeń-Mitka (2017)," The Influence of the Selected Determinants on the Development of Small and Medium Enterprises ", Journal of Eastern Europe Research in Business and Economics, Vol. 2017 (2017), Article ID 408028, 
However, high level of competition on the SME sector market makes the development of such enterprises dependent on a large number of determinants, whose proper combination may lead to market success. The development of entrepreneurship of the SME sector can be achieved by precisely adjusting the strategy of action to external business conditions and changeability of the environment (Tang et al., 2010). Currently, the factors determining the development of an organisation are very varied - they depend on a large number of variables connected with an organisation itself and its owner (manager), and result from the turbulent character of the environment, uncertainty and risk. Given that the SME sector provides around 90 million jobs and hugely contributes to the development of entrepreneurship and innovations of every country, it is important to find out the conditions and factors of its development.

The aim of the paper is to review literature on selected factors in the development of enterprises, especially from the SME sector, and, based on the Author's own research, to evaluate selected factors connected with carrying out business activity that determine the development of micro-, small and medium enterprises (SME sector). Inference is based on the results of the Author's own survey conducted on a group of 250 enterprises from the SME sector operating in Poland. During the analysis of the survey findings, basic statistics and Gamma correlation coefficient have been used showing relationships between variables.

\section{Factors determining the development of enterprises - selected aspects}

In order to achieve the aim of the paper, quantitative and qualitative analysis of selected reviewed scientific papers on the subject in question, accessible through electronic management databases, has been conducted. The process of literature review has been performed in the following, successive stages: defining the aim of the research, verifying the research aim, searching through literature in library catalogues and databases using key words, analysing the material gathered for implementation of the research aim, and comparison, verification, typology and interpretation of the content of individual sources taking into account the aims of the paper and formulated research hypotheses.

The development of enterprises, in particular factors impacting this development, is widely discussed in literature. Division of the factors determining the development of enterprises from the SMB sector is extensive, and analysis of the factors is conducted practically at every level of an organisation. For instance, factors impacting the development of enterprises include those depending on the owner of a company, its environment and those depending on an enterprise itself (Bieńkowska, 2004). Analysing the process of conducting business activity, one can distinguish factors that are connected with adopted strategy of action, company's policy towards its employees and customers (Taylor, LaBarre, 2006) as well as introduced innovations (Lee et al., 2012; Pervan et al., 2015). Moreover, factors that impact the development include, among other things, specialist skills of a company's employees and control in an organisation in the broad sense (Ashkenas et al., 1998). There is, however, no doubt that the development of an enterprise, and often its success as well, depends on the proper management of a company by its owner, or manager. Whether an enterprise adopts an appropriate strategy of action, plans its activity, adapts itself to a changing environment, employs the right people (Sipa et al., 2016), as they make a real contribution to the fulfilment of an organisation's objectives and tasks (Latifi, Shooshtarian, 2014) and create a good climate at the workplace, etc. will have an impact on how an organisation is functioning on the market. The paper is an attempt to analyse selected factors impacting the development of enterprises from the SME sector. For the purpose of this paper, review of literature on the subject has been shortened. 
An important element impacting the success of enterprises is their functioning in formal and informal networks, which underlie economic cooperation between organisations. One of the main factors influencing the development of organisations in a network is trust, which has a strongly positive direct connection with success of organisations. The bigger the networks, the more opportunities for their members, i.e. enterprises functioning as part of networks, which may impact the success of a company (Besser, Miller, 2011). Social networks created by an entrepreneur or company manager are a main factor in the identification of market opportunities (Ozgen, Baron, 2007), which in turn have a positive impact on the survival and development of a company (Watson, 2007). Thus, these ties can be classified as informal forms of cooperation between entrepreneurs from the SME sector. Tomski (2011) stresses that the motivation behind participation in cross-organisational cooperation in any of the available forms is the possibility to achieve objectives that are beyond the reach of a single enterprise. Moreover, studies on a group of small enterprises show that the adoption of a strategy of cooperation (joint operation on the market in the same industry) in the process of enterprises' activity contributes to increased competitiveness of enterprises on the market (Lemańska-Majdzik, Tomski, 2014). Cooperation of small and medium enterprises with partners allows them to be competitive not only individually but also as a team, not only on the domestic market but also on the international one (Adamik, 2011; Gołębiowski, 2010). Moreover, cooperation between smaller companies enables them to compete on the market with large enterprises and allows cooperating companies to more effectively use possessed resources, have an easier access to new, previously unattainable resources as well as easier entry into new markets (Chen, 2008).

Every organisation functions in a certain environment and at the same time impacts it and survives thanks to it. On the other hand, an organisation's environment creates certain chances and threats for it. This environment is characterised by uniqueness, which is connected with the fact that every organisation identifies its environment independently, dynamic nature, complexity of interrelated factors and different levels of control (Lisiński, 2004). However, as stressed by Dutt (2011), an enterprise functioning in a specific environment, characterised by a high level of uncertainty, changeability and turbulence, is to a large extent dependent on it. Factors impacting the effectiveness of an organisation are macroeconomic and microeconomic in character. From the perspective of an organisation management, especially an enterprise from the SME sector, it is important to appropriately analyse an organisation's environment and adapt to changing conditions. This is because the characteristics of the modern environment can become growth barriers but also a chance for creating "occasional" strategies of an enterprise. It results from the increasing complexity of an organisational system, the complexity of economic entities, the technological progress, the increased awareness of societies comprising the world of consumers and the increased level of their education (Nowodziński, 2013). Wiklund et al. (2009), based on a study of Swedish enterprises from the SME sector, stated that changeability of the environment has a directly negative impact on the growth of small enterprises (increase in sales and the number of employees). These findings show that enterprises functioning in a dynamic environment grow more slowly than enterprises functioning in a stable environment. However, if high changeability of the environment is associated with high level of entrepreneurial orientation (inclination for risk taking, proactive approach and innovativeness), a positive correlation of environment changeability with growth of enterprises is observed.

How the managerial function, i.e. planning, organising, motivating and controlling, is fulfilled affects the existence and 
development of SMEs in an increasingly competitive environment. Russu and Sima (2015) stress, that the quality of management is one of the factors impacting competitiveness and development of companies. However, for entrepreneurs (managers) to appropriately manage a company, it is necessary for them to monitor and assess the effectiveness of an enterprise on the market. According to Drucker (1994), effectiveness is a key factor in the development of an enterprise, self-fulfilment and its ability to survive. An organisation functioning in a specific changeable environment should achieve both economic and non-economic effectiveness. According to Borowiecki (2009), a characteristic of successful enterprises is the ability to use changes for survival and growth. An enterprise that reacts to changes in its environment, noticing them thanks to an analysis on a continuous basis, is characterised by flexibility of organisation, i.e. properties of an enterprise connected with its susceptibility to changes. According to Ansoff (1965), flexibility allows an organisation to cope with changes in its environment. Capability of easy and fast adaptation to changes can be an important factor of competitiveness (Kelliher, Riley, 2003; Wang et al., 2013).

Success of an organisation is undoubtedly affected by the effective management of an enterprise, and measurement and assessment of an enterprise's effectiveness requires the use of various measures of effectiveness. Thus, the basic aim of management in an enterprise is to achieve higher effectiveness of activities, with particular reference to customers' preferences and needs (Zeng, 2003). A customer turns out to be one of the most important links in the process of functioning of an organisation, as an increase in the number of customers may indicate the development of a company. Adjustment of the offer, of both products and services, as a result of enterprises' flexibility, reaction to continuous changes in the environment, adaptation process to business conditions and a proper way of management allow SMEs to develop (Philip, 2011).

\section{Research methodology and sample}

In order to achieve the aim of the paper, analysis of the results of the Author's own research was conducted. The aim of the research was to evaluate selected factors connected with the way of conducting business activity that determine the development of micro, small and medium enterprises (SME sector) operating in southern Poland.

The research used a purposive sampling. It was conducted at the beginning of 2016 on a group of 250 enterprises and was addressed to enterprises' owners or managers, who were completing survey questionnaires in a paper form in the presence of an interviewer. The evaluation of the conditions of the development of enterprises covered the last (past) 3-year period of operation on the market.

The research tool was a questionnaire survey prepared by the Author, which consisted of 24 closed and semi-open questions and demographic information. The survey questionnaire was addressed to production, trade and services companies. The questionnaire was anonymous, which encouraged respondents to express their opinions about the development of their enterprises.

When constructing questions concerning the assessment of the impact of selected factors on the development of an enterprise, a 4point Likert scale was used (a scale of forced choice) to receive more detailed opinions of respondents. From the material collected, questions connected with the subject analysed that formed a coherent whole were selected. The relationships between the variable of the declared development of an enterprise over the last 3 years and the responses to the questionnaire questions on rank (gradable) scales regarding the 
conditions of the development of enterprises were analysed by estimating Gamma rank correlation coefficient. Test probability $\mathrm{p}<0.05$ was assumed to be relevant. During the analysis of correlations, the statistical software Statistica 12.5 was used. Statistical analysis of survey results allowed the aboveformulated hypotheses to be verified.

In view of the main aim of the paper, the following research hypotheses have been formulated:

H1 - Economic cooperation with other players on the market contributes to the development of enterprises from the SME sector;

H2 - Continuous assessment of the effectiveness of the functioning of enterprises leads to the development of the SME sector.
The enterprises surveyed included 164 micro companies, employing from 0 to 9 employees, which accounted for almost $66 \%$ of the enterprises surveyed, 67 small companies, employing from 10 to 49 employees, (27\% of indications) and 19 medium enterprises, employing from 50 to 249 employees. In terms of the size, the enterprises surveyed belong to the SME sector which accounts for $99.9 \%$ of enterprises in Poland. The structure of the group is comparable with the overall structure of Polish economic entities. Bigger differences are visible within the group of small enterprises, where despite the dominant role of micro companies, which account for $65.4 \%$ of SMEs, there is a significant share of companies employing 10 49 employees (Figure 1).

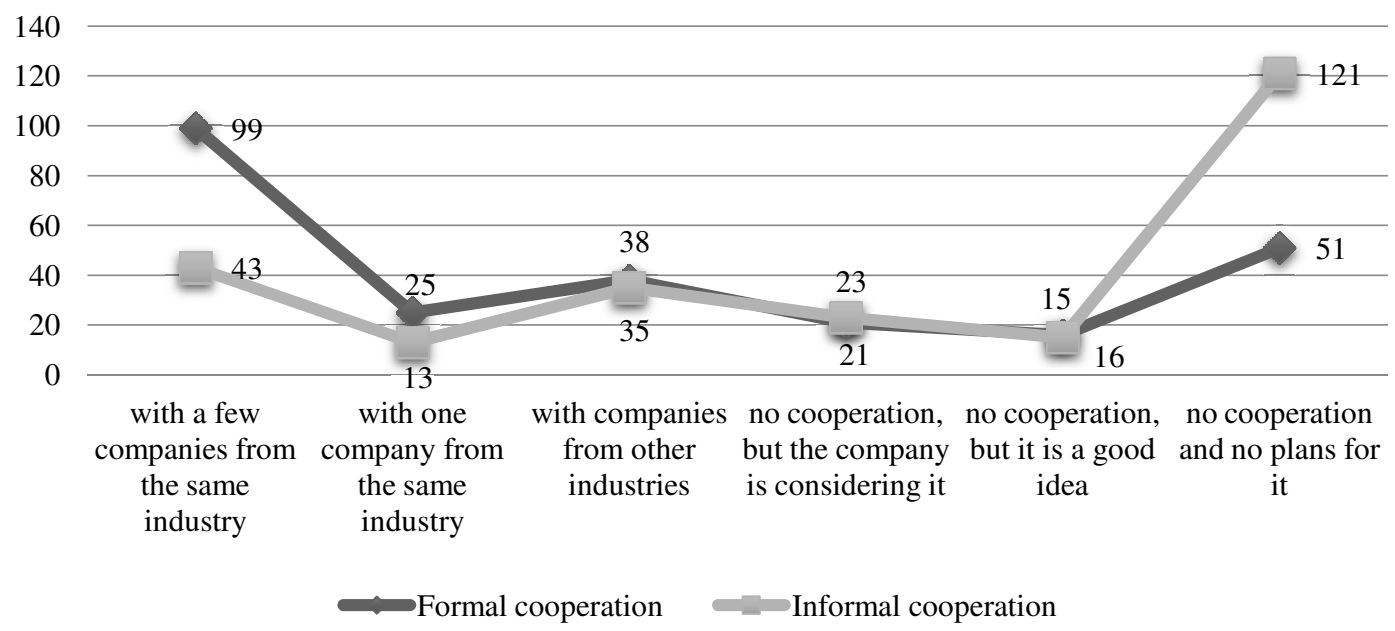

Figure1: Structure of the research sample and the economic entities SME sector in Poland

Source: Own work based on: (Bank danych lokalnych, 2016).

Services companies constituted the biggest group in the survey (83 indications), followed by trade companies $(70$ indications), production companies (only 27 companies) with 70 surveyed enterprises from the SME sector declaring the mixed profile of activity. Most companies have been functioning over 20 years, accounting for $57 \%$ of all those surveyed. The second biggest group included companies operating from 5 to 10 years, which accounted for almost $21 \%$ of all the companies. Young companies that were entering the market or have been operating for up to 5 years 
constituted $22 \%$ of those surveyed. $54 \%$ of all the companies analysed are family run businesses.

\section{Research findings and discussion}

The survey of enterprises from the SME sector made it possible to find out the number of companies cooperating as part of their activity. It was found out that cooperation was formal and informal and between both a bigger number of enterprises and single entities. Formal cooperation was declared by 162 enterprises, i.e. almost 65\% of those surveyed. Informal cooperation was indicated by $36.4 \%$ of respondents ( 91 companies). It is worth noting that $1 / 5$ of companies do not plan formal cooperation with almost 121 not planning informal cooperation (Figure 2).

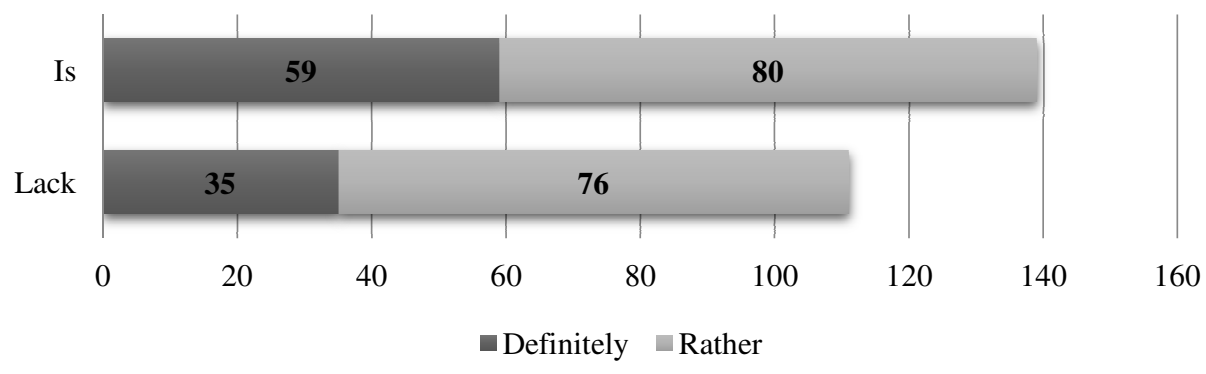

Figure 2: Formal and informal cooperation of enterprises from the SME sector $(n=250)$ Source: Own work.

These findings show that enterprises that have not cooperated earlier are cautious in this respect and find it difficult to decide to cooperate as part of their activity. This may also be due to the fact that $66 \%$ of all the companies surveyed are the smallest enterprises, whose owners have little knowledge about strategy of action or management of an enterprise.
When analyzing the economic cooperation of companies from the SME sector, it's worth paying attention to the profile of the business. It has been found out that formal cooperation is declared by over $68 \%$ of enterprises indicating a mixed profile of activity and $65 \%$ of services companies. Similar results during data analysis were received in the case of informal cooperation: $45.7 \%$ and almost $41 \%$ respectively (Table 1).

Table 1: Formal and informal cooperation of enterprises from the SME sector and business profile* $(n=250)$

\begin{tabular}{|l|c|c|c|}
\hline $\begin{array}{l}\text { Type of conducted } \\
\text { business activity }\end{array}$ & $\begin{array}{c}\text { Number of enterprises } \\
\text { in sector }\end{array}$ & $\begin{array}{c}\text { Formal } \\
\text { cooperation }\end{array}$ & $\begin{array}{c}\text { Informal } \\
\text { cooperation }\end{array}$ \\
\hline services & 83 & 54 & 34 \\
\hline trade & 70 & 43 & 16 \\
\hline manufacturing & 27 & 17 & 9 \\
\hline mixed activity & 70 & 48 & 32 \\
\hline In total & $\mathbf{2 5 0}$ & $\mathbf{1 6 2}$ & $\mathbf{9 1}$ \\
\hline
\end{tabular}

*there was a possibility of more than one answer selecting or none of them Source: Own work. 
In 59 surveyed enterprises from the SME sector, i.e. in $23.6 \%$ of the companies surveyed, there is a system for evaluation of the effectiveness of functioning in place. No such system exists in 35 companies (Figure 3). What's interesting, 156 enterprises do not have sufficient knowledge about the effectiveness of an organisation and its evaluation, therefore in practice they cannot

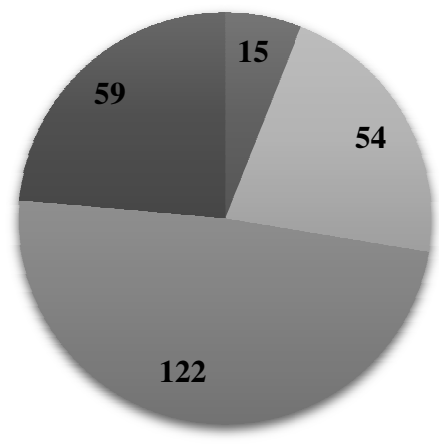

state whether such a system exists or not. These results once again confirm quite a low level of knowledge of management presented by enterprises' owners or managers. Among the 59 enterprises declaring the existence of an internal system for evaluation of the effectiveness and quality of functioning, trade companies dominate (37\% of indications).

Figure 3: An internal system for evaluation of effectiveness/quality of functioning of enterprises from the SME sector $(n=250)$

Source: Own work.

Analysis of the external environment of a company is an important aspect when conducting a business activity. It has been found out that 181 enterprises from the SME sector declare conducting analysis of their environment on a continuous basis. What's more, the companies surveyed draw conclusions from the analysis and make changes during management of the company on an ongoing basis. Such analysis is conducted by almost half, i.e. 121, the companies surveyed (Figure 4). 


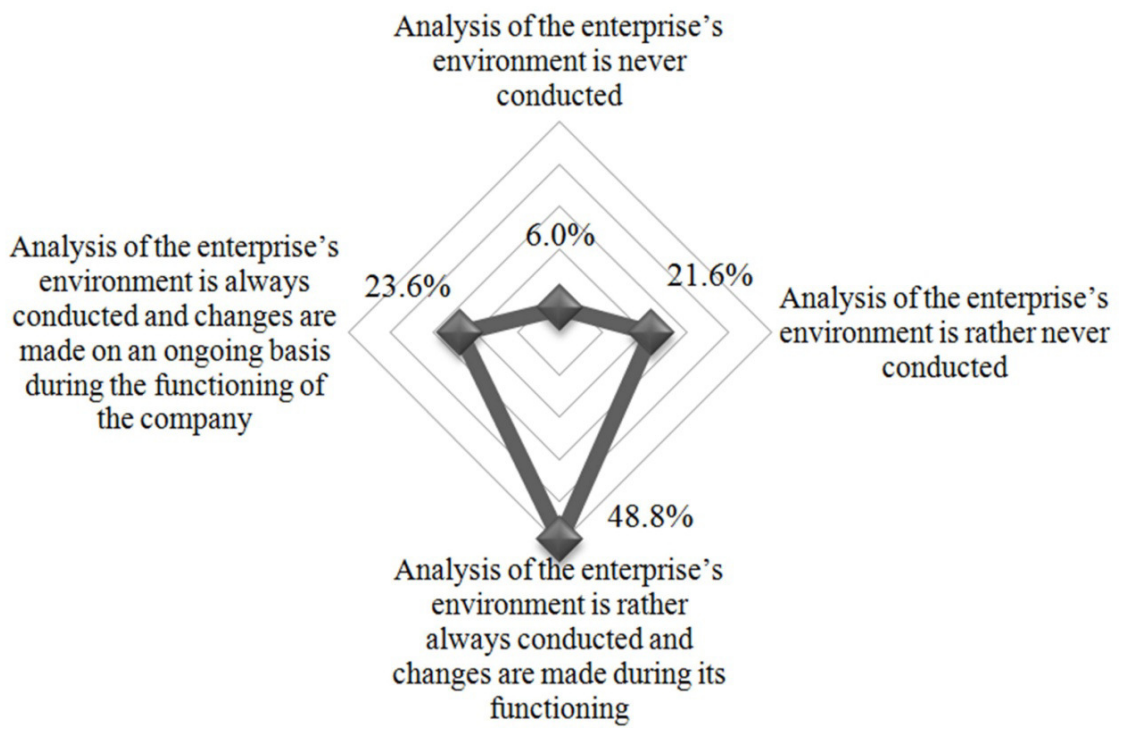

Figure 4: Analysis of an enterprise's environment and making changes on an ongoing basis during the functioning of enterprises from the SME sector (\%)

Source: Own work.

The survey has shown that the development of enterprises from the SME sector operating in southern Poland took place in the case of over $80 \%$ of companies over the last 3 years of activity, according to respondents. Such situation is described by companies' owners or managers, who define the development as noticeable. No development of an enterprise took place in the case of $20 \%$ of the surveyed enterprises from the SME sector.

The development of the companies surveyed over the last 3 years involved, for the purposes of the research: increased profit, increased investments, increased employment, increase in the number of customers and expanding the area of activity of an enterprise. It has been assumed that the above-mentioned factors are economic measures of the development of an organisation.
Enterprises from the SME sector declared similar development over the period of the last 3 years compared with earlier period of conducting economic activity. This refers to development in comparison to the main competitors on the market, the whole industry and owners' expectations. The survey shows however that, in comparison to the main competitors, the declared development of enterprises is slightly higher than in the case of expectations of company owners.

The research analysed relationships between the development of enterprises (declaration of companies' owners or managers) and cooperation as part of conducted business activity, ongoing evaluation of an organisation's effectiveness and evaluation of the company's environment and introduction of changes based on such ongoing evaluation. 
Table 2: Gamma correlation between selected factors determining the development of enterprises from the SME sector and the level of development $(n=250)$ *

\begin{tabular}{|l|c|}
\hline \multicolumn{1}{|c|}{ Factors determining the SME development } & Gamma coefficient \\
\hline $\begin{array}{l}\text { internal system for evaluation of the effectiveness/quality of } \\
\text { functioning }\end{array}$ & $\mathbf{0 . 3 0 1 * *}$ \\
\hline formal cooperation as part of the business activity conducted & $\mathbf{0 . 2 0 8}^{* *}$ \\
\hline $\begin{array}{l}\text { analysis of collected information about the company's environment and } \\
\text { making changes on a current basis }\end{array}$ & $\mathbf{0 . 1 7 5 * *}^{* *}$ \\
\hline informal cooperation as part of the business activity conducted & 0.126 \\
\hline *subjective assessment of development by enterprises' owners or managers \\
** p-value $<0.05$ \\
Source: Own work.
\end{tabular}

The survey shows that 3 out of 4 selected development-determining factors connected with the way of running business are statistically relevant $(\mathrm{p}<0.05)$ and positively correlated with the declared development of enterprises. The survey shows that formal cooperation as part of conducted business activity (Gamma $=0.208$ ), an internal system for evaluation of the effectiveness of functioning of an organisation (Gamma $=0.301$ ) and analysis of a company's environment on an ongoing basis and making changes (Gamma $=0.175$ ) have an impact on the development of enterprises from the SME sector operating in southern Poland in the past (3-year) period, which is manifested in increased profit, increased investments, increased employment, increase in the number of customers and expansion of the area of an enterprise's activity (Table 2).

\section{Summary}

The research was designed to evaluate selected factors determining the development of micro, small and medium enterprises (from the SME sector) operating in southern Poland and enabled verification of research hypotheses formulated for the purpose of the paper, namely:

- Hypothesis H1 has been partially confirmed, as it has been found out that only formal cooperation as part of conducted business activity is statistically relevant, positively correlated (gamma $=0.208 ; \quad \mathrm{p}<0.05$ ) with the development of enterprises; formal cooperation is declared by almost $65 \%$ of the companies surveyed out of $80 \%$ of those declaring noticeable development;

- Hypothesis H2 has been generally confirmed, as an internal system for evaluation of effectiveness/quality of functioning in enterprises (gamma $=0.301$ ) as well as analysis of collected information about a company's environment and making changes on an ongoing basis (gamma $=0.175$ ) are statistically relevant $(\mathrm{p}<0.05)$ and positively correlated with declared development of enterprises from the SME sector, reflected in increased profit, increased investments, increased employment, increase in the number of customers and expansion of the area of activity of an enterprise.

The findings concerning selected factors connected with the way of conducting economic activity that impact the development of enterprises from the SME sector are confirmed by research results available in the literature of the subject and 
can, according to the Authors, be a basis for further analysis of the conditions of the development of SME sector. The findings presented in the paper are only a fragment of the empirical studies conducted. The analysis conducted in this paper is part of research into development and competitiveness of enterprises from the sector of small and medium companies. The survey is complemented, among other things, by analysis which distinguishes eight determinants (Lemańska-Majdzik, Okręglicka, 2016) that can impact the current competitive position of enterprises, i.e. quality of offered products/services, company policy, company location, customer service and relations, flexibility of adapting the offer to customers' expectations, fast pace of order delivery, intensification of advertising/promotional activities or obtaining external sources of financing.

The research sample was not fully representative, therefore the research should be treated as pilot research that can be used to further explore the problem in the future by conducting representative research. However, the size of the research sample allows drawing preliminary conclusions and identifying regularities that can be verified during proper research. At the same time, it should be stressed that the data obtained are a subjective evaluation by respondents, i.e. owners or managers of enterprises.

\section{References}

1. Adamik A. (2011) 'Partnerska współpraca w strukturze procesów logistycznych MSP regionu łódzkiego', Acta Universitatis Lodziensis, Folia Oeconomica, 251, 221-234.

2. SMEs start hiring again, (2015), Annual Report on European SMEs 2014/2015. [Online], [Retrieved April 1, 2016], Available: http://ec.europa.eu/growth/smes/businessfriendly-environment/performancereview/index en.htm
3. Ansoff, H. I. (1965), Corporate Strategy: An Analytic Approach to Business Policy for Growth and Expansion, McGraw-Hill, New York.

4. Ashkenas, R., Ulrich, D., Jick, T. and Kerr, S. (1998), Boundaryless Organization. Behind the Chains of Organizational Structure, Jossey - Bass Inc. Publishers, San Francisco.

5. Bank danych lokalnych (2016, [Online], Główny Urząd Statystyczny, [Retrieved April 1, 2016], Available: http://stat.gov.pl/

6. Besser, T.L. and Miller N. (2011) 'The structural, social, and strategic factors associated with successful business networks', Entrepreneurship \& Regional Development, 23 (3/4), 113-133.

7. Bieńkowska, B. (2004), Lokalne uwarunkowania rozwoju przedsiębiorczości, Przedsiębiorczość stymulatorem rozwoju gospodarczego, Brdulak, J. and Kulikowski, M. (eds.), Instytut Wiedzy, Warszawa.

8. Borowiecki, R. (2009), Pomiar i ocena procesów kreowania wartości $\mathrm{w}$ badaniu efektywności przedsiębiorstwa, Fundacja Uniwersytetu Ekonomicznego w Krakowie, Kraków.

9. Chen, M.J. (2008) 'Reconceptualizing the competition - cooperation relationship; a transparadox perspective', Journal of Management Inquiry, 17, 288-304.

10.Drucker, P. F. (1994), Menedżer skuteczny, Wydawnictwo Akademii Ekonomicznej w Krakowie, Kraków.

11.Dutt K. (2011) 'Macroecomomics Theory after the Crisis', Review of Radical Political Economics, 43 (3), 310-316.

12.Gołębiowski, T. (2010), Kooperacja międzynarodowa a konkurencyjność polskich przedsiębiorstw przemysłu elektromaszynowego, Marketing międzynarodowy. Uwarunkowania i kierunki 
rozwoju, Wiktor, J.W. and Żbikowska, A. (eds.), PWE, Warszawa.

13.Ivanová, E. (2011), 'Interconnectivity of Factors of competitiveness at the microeconomic and macroeconomic levels in Slovakia'. Proceedings from The 9th International Conference Economic Policy in The European Union Member Countries, ISBN: 978-80-248-2458-1, 7-9 September 2011, Dolní Moravice, Czech Republic, 154166.

14.Kelliher, C. and Riley, M. (2003) 'Beyond efficiency: Some by-products of functional flexibility', The Service Industries Journal, 23, 98-113.

15.Latifi, M. and Shooshtarian, Z. (2014) 'The effects of organizational structure on organizational trust and effectiveness, Polish Journal of Management Studies', 10 (2), 7384.

16.Lee, S. M., Olson, D. L. and Trimi, S. (2012) 'Co-innovation: convergenomics, collaboration, and co-creation for organizational values', Management Decision, 5, 817-831.

17.Lemańska-Majdzik, A. and Okręglicka, M. (2016), Competitiveness of the SMEs - The Analysis of the Empirical Research Results, Proceedings of Annual Spain Business Research Conference, ISBN : 978-1-92548805-0, 26-27 May 2016, Barcelona, Spain, Available:

http://www.wbiworldconpro.com/pages/pr evious confo/spain-conference-2016

18.Lemańska-Majdzik, A. and Tomski, P. (2014) 'System MLS jako narzędzie wsparcia strategii kooperencji przedsiębiorstw świadczących usługi pośrednictwa na rynku nieruchomości', Zeszyty Naukowe Politechniki Śląskiej. Organizacja i Zarządzanie, 1921 (74), 371-382.

19.Lisiński, M. (2004), Metody planowania strategicznego, PWE, Warszawa.
20.Nowodziński P. (2013), Zarządzanie strategiczne współczesnym przedsiębiorstwem. Otoczenie a strategia, Sekcja Wydawnictw Wydziału Zarządzania Politechniki Częstochowskiej, Częstochowa.

21.Ozgen E. and Baron R.A. (2007) 'Social Sources of Information in Opportunity Recognition: Effects of Mentors, Industry Network, and Professional Forums', Journal of Business Venturing, 22 (2), 174-192.

22.Pervan S., Al-Ansaari Y. and Xu, J. (2015) 'Environmental determinants of open innovation in Dubai SMEs', Industrial Marketing Management, 50, 60-68.

23.Philip, M. (2011) 'Factors Affecting Business Success of Small \& Medium Enterprises (SMEs)', Amity Global Business Review, 6 (1), 118-136.

24.Russu, C. and Sima, C. (2015) 'Development of SMEs Sector in Romania', Valahian Journal of Economic Studies, 6 (1), 45-52.

25.Sipa, M., Skibiński, A., Gorzeń-Mitka, I. (2016), 'Intergenerational Cooperation in the Organization - View from a Gender Perspective', Proceedings of 1st International Conference Contemporary Issues in Theory and Practice of Management (CITPM 2016), ISBN: 978-83-65179-43-2, 21 - 22 April 2016, Częstochowa, Poland, 384-389.

26.Smolarek, M., (2008), Planowanie strategiczne w małej firmie, Oficyna Wydawnicza Humanitas, Sosnowiec.

27.Tang, Z. P., Kreiser, M., Marino, L. and Weaver, K.M. (2010), 'Exploring proactiveness as a moderator in the process of perceiving industrial munificence: a field study of SMEs in four countries', Journal of Small Business Management, 48 (2), 97-115.

28.Taylor W.C. and LaBarre P. (2006), Mavericks at Work: Why the Most Original Minds in Business Win, Harper, New York. 
29.Tomski P. (2011) 'Paradygmat hiperdynamiki otoczenia a współdziałanie gospodarcze współczesnych przedsiębiorstw', Zeszyty Naukowe Politechniki Częstochowskiej. Zarządzanie, 1, 7-18.

30.Wang X., Lu Y., Zhao Y., Gong S. and Li B. (2013) 'Organisational unlearning, organisational flexibility and innovation capability: an empirical study of SMEs in China', International Journal of Technology Management, 61 (2), 132-155.
31.Watson J. (2007) 'Modeling the relationship between networking and firm performance', Journal of Business Venturing, $22(6), 852-874$.

32.Wiklund J., Patzelt H. and Shepherd D. (2009) 'Building an Integrative Model of Small Business Growth', Small Business Economics, 32 (4), 351-374.

33.Zeng A. (2003) 'Global Sourcing: Process and Design for Efficient Management', Supply Chain Management: An International Journal, 8 367-379. 